Vol. 2, No. 2, 2019

\author{
V. V. Krasinskyi, V. M. Zemke, Y. M. Shapoval, Mykh. Mykh. Bratychak, N. V. Chopyk \\ Lviv Polytechnic National University, \\ Department of Chemical Technology of Plastic Processing \\ vkrasinsky82@gmail.com
}

\title{
REGULARITIES OF THE TECHNOLOGICAL RAW MATERIAL CREATION FOR EXTRUSION OF POLYETHYLENE PIPES
}

https://doi.org/10.23939/ctas2019.02.166

The technological and physical and mechanical properties of extrusion raw material for the production of polyethylene pipes of different manufacturers are research. It is determined that the dependence of composition-property is being defiined not only by the characteristics of the initial polymer raw material but also by the conditions of the mixture processing. The possibility of improving the machinability of extruded polyethylene of low fluidity by mixing it with a higher fluidity polyethylene brand has been proved. The optimum composition content on the basis of polyethylene mixtures, having sufficient manufacturability for processing of raw materials by extrusion has been grounded.

Key words: extrusion, water pressure pipes, polyethylene, mixture, index of melt flow, tensile strength, flow curves.

\section{Introduction}

The conditions of water supply market determine demand in the field of production of hightech and energy-saving materials pipelines. The pipes during its working endure considerable external and internal loads. Recently, a steady trend in use of polymer pipes instead of metal or concrete, due to their high corrosion resistance and reliability, low weight, cheap materials, high mechanical and operational properties, environmental friendliness and convenience during installation work is being observed. The largest part of polymer pipes usage is concentrated in the field of water supply and drainage for all business entities.

The growing race of the polymer tube market in ukraine is significantly ahead of other markets for polymer products which is explained by the successful competition of their operational properties with pipes made of traditional materials - steel, cast iron, concrete.

Domestic producers are mainly focused on the production of pipes made of polyethylene or its copolymers. Such pipes are most demanded in all fields of the communal sphere and industry, in particular: water, gas and heat supply, drainage, drainage systems and protection of electricity grids $[1,2]$.
Domestic production of polyethylene pipes works exclusively on imported raw materials. The quality and price of Ukrainian pipe products is determined by the quality and cost of imported polymer raw materials. Volumes of imported polyethylene into Ukraine depend on the demand for pipe products, and the demand is determined by activity of domestic construction market [3].

Ukrainian producers of polypropylene water pipes frequently note the following problems in the production which are conditioned by technical characteristics of raw materials ER $[4,5]$ :

- shagreen on inner surface of the pipe owing to insufficient homogenization of the melt and turbulence of the material flow in the extrusion head and extngruder's cylinder;

- insufficient elasticity and mechanical strength of pipe.

- low productivity of polymer raw materials.

Regarding to the above mentioned an important task in production of water pipe is obtaining of technological raw materials on the basis of polyethylene with the necessary technological capacity which will solve the above problems.

Via the previous studies [6, 7, 8, 9] was researched the rheological and technological properties of mixtures of polyolefins, in particular 
polyethylene of high and low density with ultrahighmolecular polyethylene.

The use of ultrahigh-molecular-weight linear polyethylene (UHMWPE) in polymer compositions is caused by complex of properties: high impact strength and physical and mechanical properties, non-toxicity, high resistance to aggressive media [10]. At the same time, it should be noted that the processing by such methods as injection molding and extrusion of UHMWPE is complicated due to the low melt flow index. In the previous papers, the authors obtained mixtures of ultrahigh-molecular polyethylene with polyolefins $[8,9]$, as well as filled compositions [7] through the different mixing mechanisms. The obtained composites are characterized by significant structural changes compared to the raw material due to different components affinity.

As a result, it is difficult to achieve sufficient homogeneity of the melt of such compositions, and, hence, their manufacturability.

Compositions based on mixtures of high and low density polyethylene are characterized by excellent physical and mechanical properties, but with the same chemical resistance. At the same time, they are characterized by sufficient technological capacity for processing by such high-performance methods as injection molding and extrusion $[7,8]$.

Mixtures based on ultrahighmolecular polyethylene and industrial polyolefins have sufficient technological capacity, but working properties of pipes on their basis, in particular mechanical strength are insufficient $[6,9]$.

The purpose of presented work was to research the effect of composition content on the basis of mixture of two industrial brands of extruded polyethylene with different fluidity on the rheological and physico-mechanical properties of composites and to define the optimal composition content with high technological capacity and necessary strength.

\section{Materials and methods of research}

For the research a high density extruded polyethylene of two brands were used: LITEN PL-10 (analogue to PE-80) (Unipetrol, Czech Republic) and PE2LP11-9 (analogue to PE-100) (Kazanorgsintez, Russia) in the form of black granulate.

The main data of raw materials after the technical passports are presented in Table 1.

\section{Main data of raw materials}

\begin{tabular}{|l|c|c|}
\hline \multicolumn{1}{|c|}{ Parameter } & PE2LP11-9 & LITEN PL-10 \\
\hline MFI $_{190^{\circ} \mathrm{C} / 5,0 \mathrm{~kg}, \mathrm{~g} / 10 \mathrm{~min}}$ & 0.1 & 0.43 \\
\hline Soot content, \% & $2.0-2.5$ & 2.25 \\
\hline Density, $\mathrm{kg} / \mathrm{m}^{3}$ & $956-962$ & 952 \\
\hline $\begin{array}{l}\text { Relative elongation at } \\
\text { tension, \% }\end{array}$ & $\geq 500$ & $\geq 500$ \\
\hline $\begin{array}{l}\text { Yield strength at } \\
\text { tension, } \mathrm{MPa}\end{array}$ & 21 & $18.0-20.1$ \\
\hline
\end{tabular}

Based on the value of polymer's melt flow index (MFI) you can choose a method for its processing into wares. Thus, for the injection molding relatively recommended are the polymers with MFI $\geq 1.2-7 \mathrm{~g} / 10 \mathrm{~min}$; for coating $20 \mathrm{~g} / 10 \mathrm{~min}$; for extrusion - 0,3-1.2 g/10 min [11]. From table 1, we can see that polyethylene brand PE2LP11-9 possesses a rather low MFI, which makes its processing by extrusion complicated and negatively affects the technical characteristics of the pipe.

Polyethylene of PE2LP11-9 brand were mixed with polyethylene of the LITEN PL-10 brand in ratios of $20,30,70$ and $80 \%$ by weight. The mixtures were obtained as follows: initially the components were mechanically blended, and then were melted for 15 minutes than was extruded through a nozzle with a diameter of $2.095 \pm 0.005 \mathrm{~mm}$ at a temperature of $190{ }^{\circ} \mathrm{C}$ at a load of $5 \mathrm{~kg}$ for and the strands were shredded using a rotary knife crusher. obtained agglomerate was processed on a Kuasy $32 / 25$ thermosetting machine and the samples were obtained for physical and mechanical studies in the form of standard blades at the following parameters: temperature in the zones of the injection cylinder $200,220,240{ }^{\circ} \mathrm{C}$, plastification time $90 \mathrm{~s}$, screw speed $100 \mathrm{rev} / \mathrm{min}$, the temperature of the form $20^{\circ} \mathrm{C}$, the pressure of casting $100 \mathrm{MPa}$, the time of holding under pressure is 15 seconds, cooling time -20 seconds.

The melt flow index and flow curves of the raw materials and their mixtures were determined applying the capillary viscometer of the constant pressure of the IIRT [12]. The curves were taken on an IIRT device with a capillary diameter of $2.095 \mathrm{~mm}$ and a length of $8 \mathrm{~mm}$ at different loads and at three temperatures: $190,210,230{ }^{\circ} \mathrm{C}$.

The basic physical and mechanical properties such as the elongation at breakage and the 
destructive tensile strength were determined according to ISO 527-2: 2012 [13]. Tests were conducted applying a TiraTest 2200 (Germany) discontinuous machine at the stretching speed of $50 \mathrm{~mm} / \mathrm{min}$.

\section{Results and discussion}

The maximum homogeneity of polymer mixtures is achieved when the components are characterized by close values of the melt flow index. it is also important for the regulating the physical and mechanical properties of products based on such mixtures.

In the work, the index of melt flow of raw materials and mixtures of polyethylene (Table 2 ) was determined.

The polyethylene of the PE2LP11-9 brand is characterized by a very low value of the melt flow index. In order to create the technological raw material for extrusion, it was mixed with a more fluid polyethylene LITEN PL-10 with contain from 20 to $80 \%$ by weight.

Melt flow index of composites based on mixture of polyethylenes

\begin{tabular}{|c|c|c|}
\hline \multirow{2}{*}{ Material } & $\begin{array}{c}\text { Composite } \\
\text { content, } \\
\text { \% by weight }\end{array}$ & $\begin{array}{c}\mathrm{MFI}_{190 / 5}, \\
\mathrm{~g} / 10 \mathrm{~min}\end{array}$ \\
\hline PE2LP11-9 & 100 & 0.08 \\
\hline LITEN PL-10 & 100 & 0.25 \\
\hline \multirow{3}{*}{ PE2LP11-9 / } & $80 / 20$ & 0.14 \\
\cline { 2 - 3 } LITEN PL-10 & $70 / 30$ & 0.22 \\
\cline { 2 - 3 } & $30 / 70$ & 0.40 \\
\cline { 2 - 3 } & $20 / 80$ & 0.39 \\
\hline
\end{tabular}

With an increase in content of PE of LITEN PL-10 brand in a mixture of PE2LP11-9 from 20 to $80 \%$ by weight the MFI of the obtained composites increases significantly. At the content of LITEN PL-10 in a mixture of $70 \%$ by weight the MFI of composite is $0.40 \mathrm{~g} / 10 \mathrm{~min}$, which considerably exceeds MFI of output polymers. This can be explained by the inversion of the phases during the melt flow of a mixture of two thermodynamically incompatible polyethylenes through a capillary. Mixtures based on PE2LP11-9 with the adding of LITEN PL-10 in an amount from 30 to $70 \%$ by weight are technological ones by viscosity for extrusion of water pipe made of polyethylene.
The curves of the flow of the initial polymers and their mixtures were obtained on a viscosimeter of constant pressure of IIRT at the different temperatures. The obtained results are presented in Fig. $1(\gamma-$ shear rate, $\tau-$ shear stress $)$.

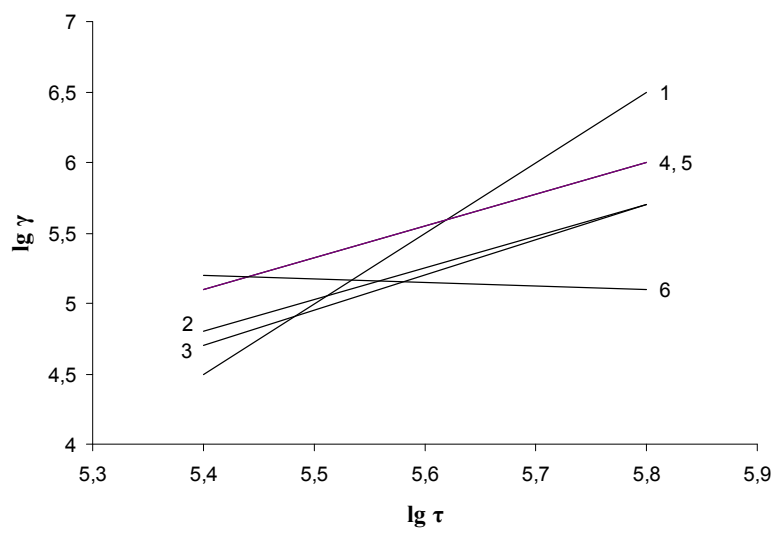

$a$

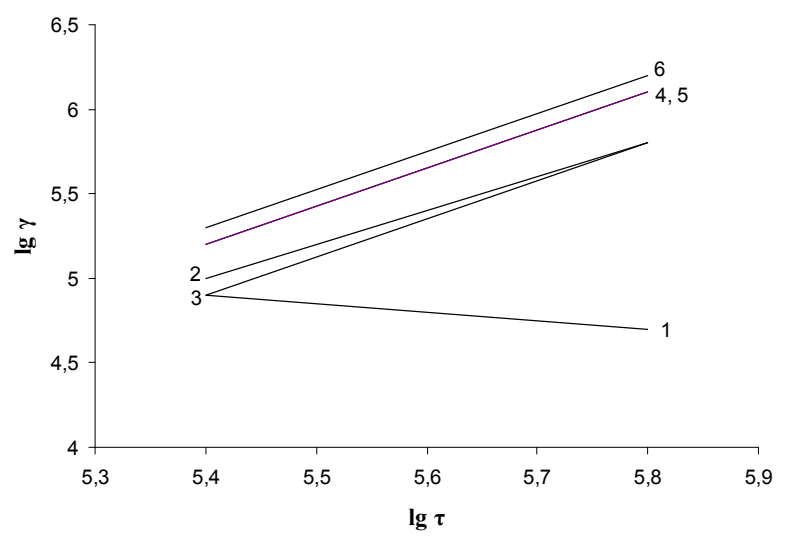

$b$

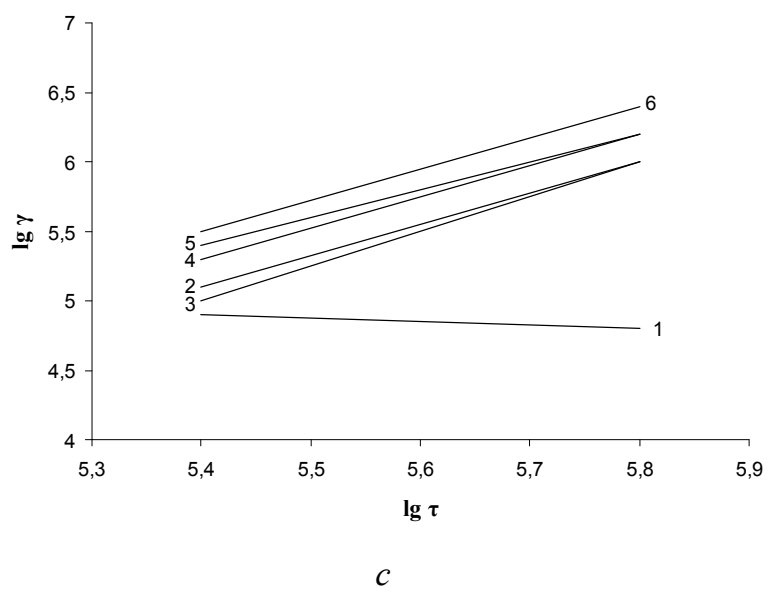

Fig. 1. Flow curves of composites based on mixtures of polyethylenes at the different temperatures:a) $190{ }^{\circ} \mathrm{C}$; b) $210{ }^{\circ} \mathrm{C}$; c) $230{ }^{\circ} \mathrm{C}$; 1 - PE2LP11-9; 2 - PE2LP11-9/ LITEN PL-10 = 80/20; $3-P E 2 L P 11-9 /$ LITEN PL-10 = =70/30; $4-P E 2 L P 11-9 /$ LITEN PL-10 = 30/70; 5-PE2LP11-9 / LITEN PL-10 = 20/80; 6-LITEN PL-10 
As you can see, all dependencies in logarithmic coordinates are linear. with the shear stress increase the deformation rate of the melt of polyethylene mixtures increases, regardless of the composition and temperature of the study. For output polyethylenes the dependence of deformation rate on shear stress is different in nature. For PE2LP11-9 at $190{ }^{\circ} \mathrm{C}$ the shear rate increases sharply with increasing stress, and at temperatures of 210 and $230{ }^{\circ} \mathrm{C}-$ decreases. For the PE brand LITEN PL-10 there is an opposite dependence - at temperatures of 210 and $230{ }^{\circ} \mathrm{C}$ the shear rate increases sharply with increasing voltage and at $190{ }^{\circ} \mathrm{C}$ - decreases.

Consequently, composites of viscosity which differed substantially from the viscosity of the initial polymers were obtained as a result of mixing two brands of polyethylene with different fluidity. mentioned results are confirmed by measurements of composites MFI.

An important technical indicator for water pressure pipes is their yield strength during stretching which should be at least $16 \mathrm{MPa}$ for LITEN PL-10 pipes and not less than $21 \mathrm{MPa}$ for PE2LP11-9 pipes [5]. The basic physical and mechanical properties of the obtained mixtures are presented in Table 3.

Table 3

Physical and mechanical properties of composites based on polyethylene mixture

\begin{tabular}{|c||c||c||c|}
\hline Material & $\begin{array}{c}\text { Composite } \\
\text { content, } \\
\% \text { by } \\
\text { weight }\end{array}$ & $\begin{array}{c}\text { Yield } \\
\text { strength at } \\
\text { tension, } \\
\mathrm{MPa}\end{array}$ & $\begin{array}{c}\text { The } \\
\text { destructive } \\
\text { tension at } \\
\text { breaking, } \\
\mathrm{MPa}\end{array}$ \\
\hline PE2LP11-9 & 100 & $24 \pm 1$ & $22 \pm 1$ \\
\hline $\begin{array}{c}\text { LITEN } \\
\text { PL-10 }\end{array}$ & 100 & $21 \pm 1$ & $20 \pm 1$ \\
\hline \multirow{2}{*}{$\begin{array}{c}\text { PE2LP11-9 / } \\
\text { LITEN } \\
\text { PL-10 }\end{array}$} & $80 / 20$ & $23 \pm 1$ & $21 \pm 1$ \\
\cline { 2 - 4 } & $70 / 30$ & $24 \pm 1$ & $22 \pm 1$ \\
\cline { 2 - 4 } & $20 / 70$ & $21 \pm 1$ & $19 \pm 1$ \\
\hline
\end{tabular}

For all mixtures the values of yield strength during stretching, which meet the requirements for pipes with PE-100 (PE2LP11-9) is obtained. The highest yield strength is characterized by mixtures based on PE2LP11-9 containing LITEN PL-10 of $30 \%$ by weight. The value of the yield strength of such mixtures is equal to the value of the yield strength of the output PE2LP11-9. The destructive tension for the breakage of obtained mixtures is also lower than the destructive tension of the output PE2LP11-9 but exceeds the destructive tensile strength of the samples made of the original LITEN PL-10.

\section{Conclusions}

The experimental method has proved the possibility of improving the manufacturability of extruded polyethylene of PE2NT 11-9 brand with low fluidity by mixing it with polyethylene brand of high- fluidity. It has been shown that due to the mixing of PE2LP 11-9 with LITEN PL-10 it is possible to significantly increase the fluidity of PE2LP 11-9 without reducing the mechanical properties of the material. For extrusion of water pressure pipes the most optimal in terms of strength and fluidity is a composition with ratio of components PE2LP 11-9 to LITEN PL-10 as 70 to $30 \%$ by weight. Such composition has the highest homogeneity (the phenomenon of phase inversion during the melt flow through the capillary does not detect), as well as high strength.

\section{References}

1. Analiz rynka plastikovoi tary i trub (PE i PP) v Ukraine. 2015 god. (n.d.). Retrieved from https://proconsulting.ua/issledovanie-rynka/analiz-rynka-plastikovoytary-i-trub-pe-i-pp-v-ukraine-2015-god [in Russian].

2. Rynok importu trubnoho polietylenu v Ukrainu. 2015 rik. (n.d.). Retrieved from http://polypipe.info/analytics/1414-rynok-importy-peykraina [in Ukrainian].

3. Petukhov, A. D, Sezonov, M. V. (2008). Rynok trubnogo polimerpererabatyvaiushchego oborudovaniia $\mathrm{v}$ Ukraine - segodnia. Polimernye truby, 2, 23-27. [in Russian].

4. Mikulonok, I. O, Vozniuk, V. T. (2010). Ekstrudovani polimerni truby. Doslidzhennia protsesu okholodzhennia. Khimichna promyslovist Ukrainy, 5, 4446. [in Ukrainian].

5. Adriadi, Iu. (2005). Primenenie trub iz polimernykh materialov $\mathrm{v}$ inzhenernykh setiakh. Polimernye truby, 2, 3-8. [in Russian].

6. Koszkul, J. (2000). Materiaty polimerowe i ich przetwórstwo: Praca zbiorowa. Częstochowa: Wydawn. Politechn.

7. Zemke, V. M, Dovha, I. V. (2013). Doslidzhennia vlastyvostei sumishei nadvysokomolekuliarnoho polietylenu $\mathrm{z}$ polimeramy vidminnoi budovy. Visnyk Natsionalnoho universytetu "Lvivska politekhnika", 761, 437-441. 
В. В. Красінський, В. М. Земке, Й. М. Шаповал, Мих. Мих. Братичак, Н. В. Чопик

8. Kurylo, M. S., Zemke, V. M., Suberliak, O. V. (2002). Anomalno velyki vidkhylennia vid adytyvnosti v zalezhnostiakh sklad - vlastyvosti v sumishakh na osnovi nadvysokomolekuliarnoho polietylenu. Visnyk Natsionalnoho universytetu “Lvivska politekhnika”, 447, 74-78.

9. Kurilo, M. S., Zemke, V. M., Suberliak, O. V. (2001). Triini polimerni sumishi - novi mozhlivosti (Master's thesis, 21 Mezhd. konf. / Slavpolikom, 2001) (pp. 63-64). Ialta [in Russian].

10. Suwanprateeb, J. (2000). Binary and ternary particulated composites: UHMWPE/CACO3/HDPE. Journal of Applied Polymer Science, 75(12), 1503. doi:10.1002/(sici)1097-4628(20000321)75:123.3.co;2-o
11. Chand, N., Kreuzberger, S., \& Hinrichsen, G. (1994). Influence of processing conditions on the tensile properties of unidirectional UHMWPE fibre/LDPE composites. Composites, 25(9), 878-880. doi:10.1016/0010-4361(94)90029-9.

12. Krasinskyi, V., Suberlyak, O., Zemke, V., Klym, Yu., Gaidos, I. (2019). The Role of Polyvinylpyrrolidone in the Formation of Nanocomposites Based on Acompatible Polycaproamide and Polypropylene. Chemistry \& Chemical Technology, 13 (1), 59-63.

13. ISO 527-2:2012. (2017, December 01). Retrieved from https://www.iso.org/standard/56046.html

В. В. Красінський, В. М. Земке, Й. М. Шаповал, Мих. Мих. Братичак, Н. В. Чопик

Національний університет “Львівська політехніка”, кафедра хімічної технології переробки пластмас

vkrasinsky82@gmail.com

\title{
ЗАКОНОМІРНОСТІ СТВОРЕННЯ ТЕХНОЛОГІЧНОЇ СИРОВИНИ ДЛЯ ЕКСТРУЗІї ТРУБ 3 ПОЛЕТИЛЕНУ
}

\begin{abstract}
Досліджено технологічні та фізико-механічні властивості екструзійної сировини для виробництва труб на основі поліетилену різних виробників. Встановлено, що залежність складвластивість визначається не лише характеристиками вихідної полімерної сировини, а і умовами перероблення сумішей. Доведено можливість покращення технологічності екструзійного поліетилену 3 низькою текучістю змішуванням його 3 маркою поліетилену вищої текучості. Обгрунтовано оптимальний склад композиції на основі суміші поліетиленів, що володіс достатньою технологічністю для переробки сировини методом екструзії.

Ключові слова: екструзія, водонапірні труби, поліетилен, суміш, показник текучості розплаву, границя текучості за розтягу, криві течії.
\end{abstract}

